\title{
The recycling of end-of-life tyres. Technological review ${ }^{(\cdot)}$
}

\author{
G. Ramos*, F. J. Alguacil* and F. A. López*
}

\begin{abstract}
In this review, a summary of current legislation applicable to End-of-Life Tyres (ELTs), management of that waste, both in Spain and Europe, and a compilation of existing technologies to enlarge the life of tyres and treatment technologies for material and energy recoveries, are provided. In recent years, there have been a number of studies in the field of treatment of ELTs, therefore applicable emerging technologies as more efficient, clean and costeffective technologies, are discussed.
\end{abstract}

\section{Reciclado de neumáticos fuera de uso. Revisión tecnológica}

\begin{abstract}
Resumen
En este trabajo, se realiza un resumen de la legislación actual aplicable a los Neumáticos Fuera de Uso (NFU), de la gestión de dicho residuo tanto en España como en Europa y una recopilación de las tecnologías existentes para la prolongación de la vida útil de los neumáticos y de las tecnologías de tratamiento para su valorización material y energética. En los últimos años, han sido numerosos los estudios realizados en el campo del tratamiento de los NFUs, por ello se ha realizado una búsqueda de las tecnologías emergentes, como posibles tecnologías más eficientes, limpias y económicas.
\end{abstract}

Palabras clave

Neumático Fuera de Uso (NFU); Recauchutado; Reciclaje material; Valorización energética. Sistema Integrado de Gestión (SIG).

\section{INTRODUCTION}

End-of-Life Tyre is that product that has become waste in accordance to the definition of waste in Article 3 a) of Spanish Law 10/1998 21 April; included in the scope, are all tyres offered on the national market, with the exception of bicycle tyres and those with a diameter exceeding $1400 \mathrm{~mm}$ [1]. The code that corresponds according to the European Waste List (EWL) is "16 01 03", unique or widespread in the chapter on "Waste not otherwise specified in the list"[2].

ELT is a special waste with environmental, economic and social issues. In addition, the tyre is a high-energy material which justifies the efforts in the advancement of technology, innovation and research and development. In Spain, 238,529 tonnes of ELTs were generated in 2008, while in Europe
3,4 million tonnes were generated. Therefore, the aim of this paper is to present the current status of recycling of ELTs, focusing on existing and emerging technologies for treatment.

\section{COMPOSITION OF TYRE}

Tyres vary in size and design according to their use and manufacturer. However, the composition is very similar (Table I) ${ }^{[3]}$.

The rubber is the tyre main component; five types of rubber are used: natural rubber (NR), StyreneButadiene Rubber (SBR), Polybutadiene Rubber (BR), Isobutylene-isoprene Rubber (IR) and Isobutylene-isoprene Halogenated Rubber ${ }^{[4]}$.

Textiles and metals are also part of the tyre. Currently steel cord are used to reinforce the rubber

(•) Trabajo recibido el día 21de Septiembre de 2010 y aceptado en su forma final el día 15 de Octubre de 2010.

* Centro Nacional de Investigaciones Metalúrgicas (CENIM). CSIC.Avda. Gregorio del Amo, 8. 28040 Madrid, Spain.

Corresponding author: flopez@cenim.csic.es 
Table I. Main components and characteristics of tyres mean values

Tabla I. Principales componentes y características de los neumáticos con valores medios

\begin{tabular}{|c|c|c|}
\hline & & Function \\
\hline Composition & $\begin{array}{c}\text { Rubber } 45 \text { - } 47 \% \\
\text { Carbon black } 21.5 \text { - } 22 \% \\
\text { Steel } 16.5 \text { - } 25 \% \\
\text { Textile } 5.5 \% \text { (Passenger car) } \\
\text { Zinc oxide } 1 \text { - } 2 \% \\
\text { Sulphur } 1 \% \\
\text { Additives } 5-7.5 \%\end{array}$ & $\begin{array}{c}\text { Structural-strain } \\
\text { Physical properties improved } \\
\text { Structural skeleton } \\
\text { Structural skeleton } \\
\text { Catalyst } \\
\text { Vulcanizing agent }\end{array}$ \\
\hline Heavy metals & $\begin{array}{l}\text { Copper, cadmium and lead } \\
\text { trace content }\end{array}$ & \\
\hline High calorific value & $\begin{array}{c}32-34 \mathrm{MJ} \mathrm{Kg}^{-1}(1 \text { Ton } \\
\text { is equivalent to } 0,7 \text { Ton } \\
\text { petroleum) }\end{array}$ & \\
\hline Autoignition temperature & $400{ }^{\circ} \mathrm{C}$ & \\
\hline Weight & $\begin{array}{c}6.5-11 \mathrm{Kg} \text { (Automobile) } \\
50-80 \mathrm{Kg} \text { (Trucks) }\end{array}$ & \\
\hline
\end{tabular}

compound and provide strength ${ }^{[5]}$. Among the materials suitable for use cotton, rayon, polyester and steel are included ${ }^{[4]}$.

The type and the percentages of other minor components depend on each manufacturer. These components are additives, sulphur compounds, and other hazardous compounds such as heavy metals (Table II) ${ }^{[6]}$. Furthermore, the tyres are produced using oils that may contain significant levels of Polycyclic Aromatic Hydrocarbons (PAHs), added unintentionally ${ }^{[7]}$.

\section{LEGISLATIVE FRAMEWORK}

Recently the European Union (EU) adopted Directive 2008/98/EC in waste policy ${ }^{[8]}$. This repealed Directives 75/439/EEC, 91/689/EEC and 2006/12/EC as of December 12, 2010, becoming the new framework law on waste of European Community, to which all Member countries must adapt. Spanish adaptation to this law is under progress, this is because Law 10/98 on waste still remains in effect.

Directive 1999/31/EC on the landfill of waste appears the Royal Decree 1481/2001 incorporating it into internal right ${ }^{[9]}$.
Directive 2000/53/EC on vehicles at the end of its useful life, including measures to prevent waste from vehicles such as tyres ${ }^{[10]}$.

Currently in Spain, the second ELT National Plan 2008-2015 is in effect, part of the Waste National Plan 2008 - 2015.

The first specific legislation comes with Royal Decree 1619/2005 on the management of used tyres, approved under Articles 1 and 7 of Law 10/98 of waste.

EU adopted the Directive 2000/76/EC on waste incineration that sets emission limits for all new cement kilns manufactured as of 2003. Royal Decree $653 / 2003$ on waste incineration is adopted, with the aim to minimize the environmental impacts of the activities of incineration and co-incineration of waste ${ }^{[11]}$.

Finally, Directive 2005/69/EC restricts the marketing of tyres containing hazardous substances such as $\mathrm{PAHs}{ }^{\left[{ }^{[6]}\right.}$.

\section{PRODUCTION AND TREATMENT}

In recent years, the evolution of the amount of generated ELTs have been reduced (Table III) and 
THE RECYCLING OF END-OF-LIFE TYRES. TECHNOLOGICAL REVIEW RECICLADO DE NEUMÁTICOS FUERA DE USO. REVISIÓN TECNOLÓGICA

Table II. Hazardous components in tyres and regular contents. (UNEP, 2008)

Tabla II. Componentes peligrosos de un neumático y contenido habitual. (UNEP, 2008)

\begin{tabular}{ccc}
\hline Component & Content (\% weight) & Content (g) \\
\hline $\begin{array}{c}\text { Copper compounds } \\
\text { Cadmium compounds }\end{array}$ & $\begin{array}{c}\text { Approx. 0.02 } \\
\text { Max. 0.001 }\end{array}$ & $\begin{array}{c}\text { Approx. } 1.4 \\
\text { Max. 0.07 }\end{array}$ \\
\hline $\begin{array}{c}\text { Zinc compounds } \\
\text { Lead compounds }\end{array}$ & $\begin{array}{c}\text { Approx. 1 } \\
\text { Max. 0.005 }\end{array}$ & $\begin{array}{c}\text { Approx. 70 } \\
\text { Max. 0.35 }\end{array}$ \\
\hline $\begin{array}{c}\text { Acidic solutions or acids in solid form } \\
\text { Organohalogen compounds }\end{array}$ & $\begin{array}{c}\text { Approx. 0.3 } \\
\text { Content of halogens } \\
\text { Max. 0.10 }\end{array}$ & $\begin{array}{c}\text { Approx. 21 } \\
\text { Content of halogens } \\
\text { Max. } 7\end{array}$ \\
\hline $\begin{array}{c}\text { Polycyclic Aromatic Hydrocarbons } \\
\text { (PAH) }\end{array}$ & 0 (After 1 January 2010) & 0 \\
\hline
\end{tabular}

Table III. Evolution of the ELTs generation in Spain and Europe. For a car tyre weighing $7 \mathrm{Kg}$

Tabla III. Evolución de la generación de NFU en España y en Europa. Estimado para un neumático de coche de $7 \mathrm{Kg}$

\begin{tabular}{ccccc}
\hline & & 2005 & 2007 & 2008 \\
\hline SPAIN & Generated (t) & 302000 & 250833 & 238529 \\
EUROPE & Generated (t) & $2738000($ EU-15) & $4800000($ EU-28) & $3400000($ EU-28) \\
\hline
\end{tabular}

the managed quantities have increased (Fig. 1), both for Spain and Europe. In Europe, 65 \% of the generated ELT were going to landfills in 1992, and the amount was reduced to $35 \%$ to $13 \%$ and $6 \%$, in 2002, 2005 y 2008 respectively. The recovery of materials is the most popular treatment ${ }^{[12]}$. In Spain, the storage in landfills has also reduced in the last seven or eight years ${ }^{[12]}$, increasing significantly others treatment options mainly in the recovery of materials.
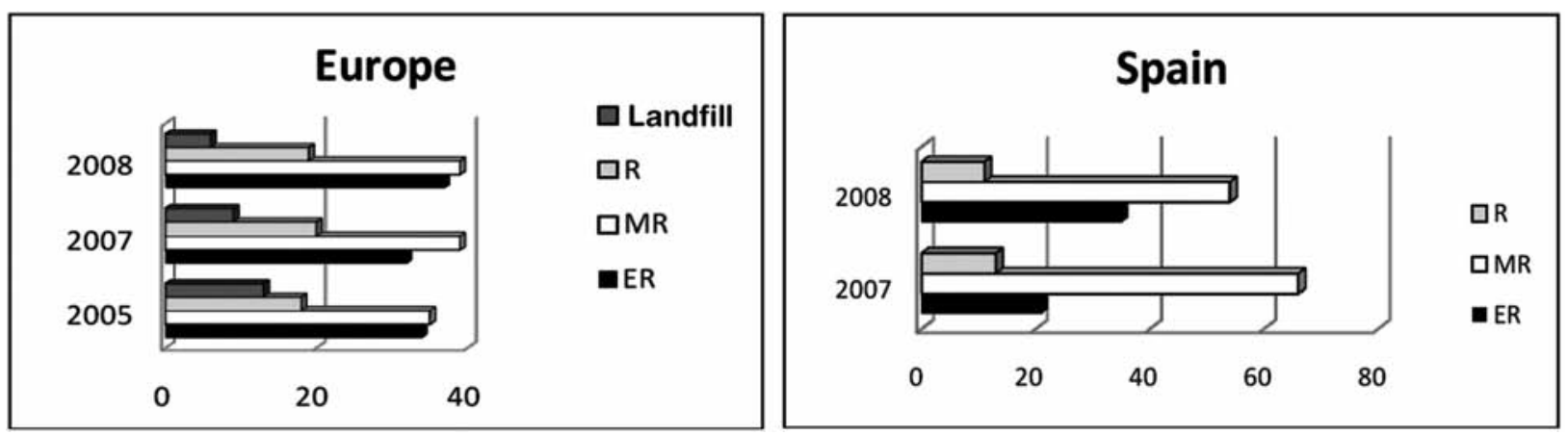

Figure 1. Evolution of ELTs destination in Europe and Spain. (R: Reuse, MR: Material Recycling; ER: Energy Recovery).

Figura 1. Evolución del destino de los NFU's en Europa y España. (R: Reutilización; MR: Valorización Material; ER: Valorización Energética). 


\section{ELTS MANAGEMENT}

\section{a. Europe}

Tyre manufacturers and importers have been required to make big changes on the management of ELTs due to Directive 1999/31/EC. In Europe three ELTs management systems exist today: i) Producer Responsibility as non-profit ELTs managing specialized companies (in 18 European countries), ii) free market system that not designated the responsible and iii) the tax system, where responsibility is of a given government.

\section{b. Spain}

Currently, ELTs management strategy is based on principle of producer responsibility, where participating manufacturers or importers buy tyres in other EU member state. In Directive 98/2008/CE on waste, this principle should be replaced by the principle of extended producer responsibility that includes the active participation of producers due to the new policy framework ${ }^{[8]}$.

The targets, measures and indicators for the ELTs management are set out in the ELT National Plan, in Spain ${ }^{[13]}$.

In Spain, two Integrated Management System (IMS) are active: "Ecovalor SIGNUS SL", is the first ELTs managing company which was constituted in May 2005, this IMS have attached 149 producers and 30,055 generation points and "Tratamiento Neumáticos Usados SL (TNU)", was constituted by the National Association of Importers of Tyres (ASINME) in June 2006 to which 140 producing companies and 6,000 workshops were attached. Both must charge for each tyre placed first in the market (costs applicable to the ELT management are under Royal Decree 1619/2005) to manufacturers attached, respectively.

\section{ELT DESTINATION}

The management begins with ELT delivery by the user for free and collection in ELTs generators points by contracted companies. The selection with inspection are carried out to decide what can be reused, whole recovered, and which ones can go to recovery to be transformed into a new product or energy, already in the collection and classification centre.
The tyres are sent to recovery facilities processing that can be shredder and/or grinder, after the selection. ELT will be necessary to the whole recover, for example civil works, only shred for use as fuel, or shred and granulate for material recovery, depending on the application.

In order to give adequate coverage to all Regional Governments with which the IMC's have an agreement, both management have their facilities in strategic locations and throughout the Spanish territory.

\section{ELTS TREATMENT TECHNOLOGIES AND APPLICATIONS}

\subsection{Technologies for reuse: retreading}

It is a process that allows reuses the tyre casing to put a new tread, thus preserving the qualities that ensure its use as new. In Spain, truck tyres are mainly retread (approximately $75 \%$ of retreading) because they are more accepted in the market and tend to be better care; but car, plane, and industrial tyre, can be also retreaded. There are some retreading tyres plants in Spain.

There are two Regulations about retreaded tire (ECE Regulation 108 for private (passenger) cars and their trailers and ECE Regulation 109 for commercial vehicle $\left.{ }^{[4]}\right)$ ), that certify the quality of facilities and production processes of the retreaded tyres manufacture, with controls and tests on similar product to those required for approval of new tyres.

There are three retreading systems according to renewed surface ${ }^{[14]}$ :

- Integral, renewing the tread and sidewall.

- Semi-integral, renewing the tread and part of the sidewall.

- Only the tread. There are two retreading systems according to adhesion system:

- Hot retreaded, the vulcanization process is carried out in pressing machines at temperatures comprised between $150-160^{\circ} \mathrm{C}$.

- Cold retreaded, the vulcanization process is carried out in autoclaves at temperatures between $98-125^{\circ} \mathrm{C}$.

Retreading reduce raw material costs (30 - 50\%) and the ELTs generation, and yields the same benefits as a new tyre ${ }^{[5}$ and 6$]$. As for drawbacks, the number of retreaded supporting a tyre is limited, and its features are reduced at times ${ }^{[15]}$. 


\subsection{Technologies for material recycling}

\subsubsection{Shredding technologies}

\subsubsection{Mechanic shredder}

In Spain, the most typical transformation for material recycling is the shred. The cut is performed with shearing crusher two or more parallel axes blades which spin at different speeds. The separation of the axes defines the final size, being able to find these fractions ${ }^{[19]}$ :

- Shred small or $50 \times 50 \mathrm{~mm}$ is mainly used as fuel in cement kilns.

- Shred medium or $100 \times 100 \mathrm{~mm}$ is used as fuel or material recovery.

- Shred large or $150 \times 150 \mathrm{~mm}$ has applications in civil engineering, for example, sealing of landfills, road construction, slope stabilization, road and railway embankments, drainage material (replacing sand and gravel), landfill construction, sound barriers, insulation, etc. If not used for these applications, the shred material is used as before to move to granulation later.

\subsubsection{Cryogenic shredder}

This technology uses liquid nitrogen to cool the tyre to temperatures between from $-50^{\circ} \mathrm{C}$ to $-100{ }^{\circ} \mathrm{C}$, in which the rubber enters the glass state, becoming very fragile and is therefore easier to shred ${ }^{[14]}$. The semi-cryogenic shredder is a variation, where only liquid nitrogen is applied to certain parts of the tyre ${ }^{[16]}$.

Shredded tyre allows to facilitate transport, the reduction of volume and the homogenization of the waste and for use in several applications. The disadvantages, there is considerable wear on the blades and its subsequent renewal requires a high cost. Moreover, all sizes shred have not real applications today, and there are not many studies to improve the technique ${ }^{[15 \text { and } 16]}$.

\subsubsection{Grinding technologies}

\subsubsection{Ambient grinding}

Ambient grinding works by crushing against metal rings provided with holes ${ }^{[16]}$. The equipment can be powered by shovelling into the hopper or directly by conveyor belt from the grinding process. It is important pre-shred for the feed with a material has a uniform size as possible. There is a trommel for classifying the rubber in three fractions after of grinding ${ }^{[16]}$ :

- Granulation 2.5 - $4 \mathrm{~mm}$ has the most applications.

- Pulverization 0.8 - $2.5 \mathrm{~mm}$ has a great demand for artificial grass, as synthetic fiber filling with aggregate or as a base layer.

- Micronization $<0.8 \mathrm{~mm}$ its use is supported by Public Administration and when mixed with bitumen, asphalt can be manufactured.

Granulate have irregular shape with a considerable surface roughness and the rubber is partially oxidized at the surface due to heat generated during the process $^{[14]}$.

\subsubsection{Cryogenic grinding}

The shredded rubber is cooled below the freezing point of $-200{ }^{\circ} \mathrm{C}$ so that it becomes fragile and disappearing its elasticity and thus it can be easily disintegrated. This process uses liquid nitrogen first, and then the rubber passes through an impact mill (similar to a hammer) where it is ground. This technology enables rapid separation of the three components of tyres (rubber, steel and fibres) on drying ${ }^{[6]}$.

The shape, size distribution and surface characteristics of grinding rubber obtained by cryogenic grinding are different from those obtained by ambient grinding. The granulate have a relatively smooth surface, a wide range of particle size and minimal surface oxidation ${ }^{[14}$ and 17$]$.

In Spain the first cryogenic grinding has been installed in Valdemoro (Madrid) operated by the company "Cauchos Valdemoro". In Europe there is only a similar plant in Germany.

\subsubsection{Wet grinding}

It is a rarely used process that consists of a series of grinding wheels that inject into the surface of the tire high-pressure water spray for cooling of dust rubber. After, this process separates the water from dust and dried ${ }^{[14]}$.

Many products can be obtained from the different sizes of grinded rubber, and for each use is required a particular size (Table IV) [18 and 19].

The advantages of grinding technologies are to get fine and regular particles with variable size 
Table IV. Examples of granulated ELT employed in different products. (UNEP, 1999)

Tabla IV. Ejemplos de granulado de distintos tamaños usados para algunos productos (UNEP, 1999)

\begin{tabular}{lc}
\hline \multicolumn{1}{c}{ Product } & Size $(\mathrm{mm})$ \\
\hline Carpet backings & $0.8-1.6$ \\
Moulded products & $0.5-5$ \\
Playgrounds & $1.6-2.5$ \\
Road paving materials & $0-0.8$ \\
Running tracks/Sport field & 1.6 \\
Shoe soles & $0.4-1.6$ \\
Train and tram rails & $0.4-1.6$ \\
TDF & $<25-<50$ \\
\hline
\end{tabular}

distribution, as the granulate has greater scope in many applications ${ }^{[19]}$. The cryogenic grinding technology offers other advantages such as temperature monitoring, the existence of an inert atmosphere by avoiding the deterioration of rubber, it improves the surface morphology of the particles and smaller particles are obtained. Against, the grinding technologies have higher investment than shredding technologies. The wet and cryogenic grinding requires drying and can cause the leaching of $\mathrm{ZnO}$, under certain environmental conditions (due to zinc compounds which are part of tire additives $)^{[5]}$.

\subsection{Energy recovery}

\subsubsection{Cement industry}

In Europe, the cement sector is the main use of tyres as an alternative fuel source (Tire-Derived
Fuels TDF) (Table V) [20]. European legislation is adapted to permit and limit its use and emissions. ELT is an alternative fuel today, but it cannot exceed $20 \%$ of total fossil fuel required in the manufacture

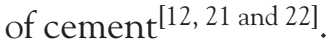

The $60 \%$ of ELTs generated are used as fuel in cement kilns in Austria; while in Germany, France and Britain are used the $38 \%$ and $8 \%$ and $6 \%$, respectively. In Spain, there are several cement kilns using whole or shredded tires as TDF.

The clinker obtained from TDF by $20 \%$ substitution of conventional fuel is similar to that obtained using only pet coke ${ }^{[23]}$. For the moment, there are not scientific data showing a decline in the quality of the final product using this fuel.

\subsubsection{Steel plants}

Shredded tyres can be used in electric arc furnaces as a substitute for anthracite $(1.7 \mathrm{Kg}$ ELT is equivalent to $1 \mathrm{Kg}$ of anthracite $\left.{ }^{[24]}\right)$ and part of the scrap. In addition to the use of the calorific value of the tyre, all the steel contained in tires is recycled $^{[24}$ and 25$]$. All without any appreciable changes in the levels of emissions of certain pollutants such as steelmaker dust and gases, and it may be even smaller, as in the case of heavy metals and $\mathrm{CO}_{2}$ (Table VI) ${ }^{[24]}$.

The key is to introduce into the electric arc furnace a mixture of scrap and ELTs. The content carbon tire contributes to the reduction of iron, saving consumption of reducing agent, the iron in the tyre joined the molten phase, improving metallurgical performance; and zinc in the tyre, joins the steel powder ${ }^{[26]}$. About 1,3 million per year ELTs are used in this way in U.S.. In Japan, the $4 \%$ of total ELTs managed were spent in this way, by 2008 [27]. Recently, Belgium, France and Luxembourg have applied its industrial use and it has potential for growth in the rest of Europe ${ }^{[12]}$. Spanish have it as medium-term objective ${ }^{[13]}$.

Table V. Worldwide usage of ELTs as TDF. (WBCSD, 2007)

Tabla V. Uso de los NFU como CDN en el mundo. (WBCSD, 2007)

\begin{tabular}{lccl}
\hline & $\begin{array}{c}\text { ELTs production } \\
\text { (Mton) }\end{array}$ & $\begin{array}{c}\text { Percentage used } \\
\text { as TDF (\%) }\end{array}$ & \multicolumn{1}{c}{ Facilities using ELTs as TDF } \\
\hline Europe & 2.50 & $41(2006)$ & Cement kilns \\
Japan & 0.80 & $70(2006)$ & Cement kilns, paper mills, tyre factories \\
U.S. & 2.92 & $53(2005)$ & Cement kilns, paper/pulp mills, boilers \\
\hline
\end{tabular}


THE RECYCLING OF END-OF-LIFE TYRES. TECHNOLOGICAL REVIEW RECICLADO DE NEUMÁTICOS FUERA DE USO. REVISIÓN TECNOLÓGICA

Table VI. Energy potential and $\mathrm{CO}_{2}$ emission from fuels. (UNEP, 2008)

Tabla VI. Energía contenida y emisión de $\mathrm{CO}_{2}$ de combustibles. (UNEP, 2008)

\begin{tabular}{lccc}
\hline \multicolumn{1}{c}{ Fuel } & $\begin{array}{c}\text { Energy } \\
\text { (GJ/ton) }\end{array}$ & $\begin{array}{c}\text { Emissions } \\
\left(\mathrm{KgCO}_{2} / \text { ton }\right)\end{array}$ & $\begin{array}{c}\text { Emissions } \\
\text { to energy } \\
\text { ratio } \\
\text { (Kg CO} / \text { /GJ) }\end{array}$ \\
\hline Tires & 32.0 & 2.270 & 85 \\
Carbon & 27.0 & 2.430 & 90 \\
Pet Coke & 32.4 & 3.240 & 100 \\
Diesel oil & 46.0 & 3.220 & 70 \\
Natural gas & 39.0 & 1.989 & 51 \\
Wood & 10.2 & 1.122 & 110 \\
\hline
\end{tabular}

\subsubsection{Alternative fuel in thermal power stations and pulp and paper mills}

At present, the use of ELTs as an alternative fuel in these industries is widespread in the U.S., and especially in Japan, but not in Europe ${ }^{[27]}$. U.S. consumed 39 million tons of ELTs in 24 paper mills in 2005, and Japan $32 \%$ of ELTs generated in 2008, percentage which is much higher than that used in the cement industry, which was $13 \%{ }^{[27]}$.

\subsubsection{Other industrial boilers}

This particular application is used mainly in Japan, which uses $2 \%$ of ELTs for energy recovery in 8 of the 21 tyre factories existing and $1 \%$ in other industrial boilers ${ }^{[27]}$.

The great advantage of the tyre as TDF is its highenergy content (Higher Heating Value $32 \mathrm{KJ} / \mathrm{Kg}$ ) and it is equal or better source of energy than other fuels (Table VI) ${ }^{[12]}$. ELTs can generate energy as heat, electricity or cogeneration and can be co-incinerated or used as the only source of energy in many processes. Furthermore ELTs can be used whole, shred or granulated.

Many studies shown that the use of ELTs reduces emissions, for example $\mathrm{SO}_{\mathrm{x}}$ because tyre contains less sulphur than conventional fuel, and emissions of greenhouse gases such as $\mathrm{CO}_{2}$ because the carbon content per unit of energy is lower than in coal and pet coke ${ }^{[28}$ and 29$]$. The ash produced generally contents fewer heavy metals than the ash coal combustion because in the cement kiln the rubber provides energy and iron and sulphur are incorporated into the cement ${ }^{[21 \text { and 22]. }}$
The biggest disadvantage of ELTs energy recovery is its limited use as a $10-20 \%$ alternative fuel. Furthermore, its weight and volume because it limits the distance from transport and the availability and the high temperatures reached in combustion, because it poses a high standard in terms of furnaces and refractory linings used (due to differences in burning rate of the various components, the difficulty of feeding the system and the presence of metals and metal oxides).

\section{EMERGING TECHNOLOGIES}

\subsection{Road applications}

The use of ELTs dust in the construction of roads is one of the most important applications. The production of bituminous mixtures with dust tire is a relatively old technology because it has been developed as in the U.S. since the 60s . Rubber asphalt is expanded in the U.S., and Europe is expected to grow in the future ${ }^{[4]}$. Today, Spanish oil companies have the necessary technology and research laboratories for the incorporation of rubber granulates for bituminous mixtures, but this application is taking place only in few projects (approximately only $3 \%$ of ELTs managed are for the purpose $)^{[14]}$.

In Spain there is an "User manual rubber asphalt" which reflects the state of the art in knowledge and experience to help technicians and authorities responsible to use properly this material ${ }^{[30]}$.

There are three types rubber-modified concrete:

- Rubber Modified Bitumen (BMC) has properties similar to polymer-modified bitumen and the amount of dust needed is $12-15 \%$ by weight. It can be used for the same applications as polymer-modified bitumen: a layer of rolling thin staple $\mathrm{F}$ and $\mathrm{M}$, blends and mixes draining $S$ intermediate layer with improved properties of fatigue and plastic deformations.

- Rubber Modified Bitumen with High Viscosity (BMAVC) is manufactured with a higher proportion of dust rubber, between $15-22 \%$ by weight and is used in applications where very high viscosity is required.

- Rubber Improved Bitumen (BC) has better features than the conventional bitumen and the percentage of dust rubber used is usually between $8-12 \%$ by weight. It has intermediate properties between conventional and modified bitumen. Its principal application is as basic and intermediate layers and as wearing courses 
with conventional mixtures of heavy traffic categories $\mathrm{T} 1$ to $\mathrm{T} 4$.

There are two main processes for producing rubber asphalt ${ }^{[30]}$ :

- Wet process: dust rubber is added to bitumen at high temperature $\left(149-190^{\circ} \mathrm{C}\right)$ which causes the rubber to soften, absorb the lighter components of bitumen and swelling. The mixture should be in continuous agitation so as not to segregate ${ }^{[31]}$.

- Dry process: dust rubber is added directly into the asphalt manufacturing plant, as if it were a mineral fraction. The dust acts partly as an aggregate, but the finest particles interact with bitumen modifying its properties. There are two techniques depending on the maximum size of dust rubber. One uses high maximum sizes of up to $2 \mathrm{~mm}$, and the other technique uses less dust rubber size $<0.5 \mathrm{~mm}$ and a lesser proportion.

The application in the road of recycled rubber has great advantages mainly because it saves nonrenewable raw materials, large volumes are needed in each project, and road construction takes place around the country. In addition, dust rubber improves the properties of conventional bitumen and governments encourage its use ${ }^{[31 \text { and } 32]}$. However, it competes at a disadvantage with the low prices of petroleum products and aggregates and moreover, the cost of treatment for dust rubber is high.

\subsection{Devulcanization}

It is a process of decomposition that allows the recycling of rubber from ELTs based on chemical bond breaking cross monosulfide, disulfide and polysulfide (carbon-sulfur and sulfur-sulfur bonds) of vulcanized rubber ${ }^{[33]}$. The aim of the devulcanization of rubber is a product with properties similar to virgin rubber to return to revulcanize with or without the use of other compounds, and then to produce rubber mould applications. The devulcanization is an expensive technology but some applications have been developed and the investigation continues. Some of the existing processes are devulcanization chemical, bacterial, thermal, microwave, mechanical, ultrasonic, chemical-mechanical, thermo-mechanical and thermo-chemical and other ${ }^{[34]}$. They are only a small number of operating systems but with small capacity. The greatest potential for productive areas of research is to reduce processing costs and obtaining rubbers with properties identical to virgin rubber $^{[34]}$. In Spain is not yet installed any devulcanization plant.

\subsection{Pyrolysis}

Pyrolysis is the thermal degradation process of shred or granulated tire in intermediate substances such as gas, oil, solid residue (char or carbonaceous solid residue) and steel. In the pyrolysis process, shred tire $(1-3 \mathrm{~cm})$, or granulated tire $(0.5-4 \mathrm{~mm})$ free from steel and textiles are heated at a moderate temperature $\left(400-800{ }^{\circ} \mathrm{C}\right)$ in the absence of oxygen or a limited amount ${ }^{[35]}$. The overall reaction which takes place in a reactor is described as follows ${ }^{[35-42]}$ :

- Organic material (rubber) is fed to the pyrolysis reactor and is subjected to thermal cracking, breaking up into a volatile fraction and a solid residue.

- Volatile fraction is cooled, and thus resulting two fractions: a liquid fraction and a noncondensable gas fraction.

- Condensable liquid fraction is about $35 \%$ of the initial weight. This fraction is commonly called tire-derived oil and it consists of organic compounds $\mathrm{C}_{5}-\mathrm{C}_{20}$. Mainly, tire-derived oil consists of: $\mathrm{PAH} ` \mathrm{~s}$ comprising naphthalene and its derivatives (methyl, ethyl, dimethyl, trimethyl, tetramethyl and ethenyl naphthalene), indene and its derivatives (methyl, dimethyl, dimethyl-1H, trimethyl and dimethyl dihydro indene) and indan. The group includes derivatives of benzene and ethyl benzene, methyl, propyl, methyl ethyl, trimethyl, tetramethyl and methylpropyl methyl benzene, toluene and isopropyl toluene and xylenes (ortho, meta and para xylenes). On the azo group and parent derivatives, including organic compounds containing nitrogen and sulphur in its structure, mainly benzothiazole, thiophene and its derivatives (methyl, dimethyl and dimethylbenzotiophene) benzonitrile, dimethylquinolein. These last two compounds are used in most formulations of the tires. Finally, aromatic compounds group consists of alkanes and alkenes, mainly cyclical (cycle butane, dimethyl hexene cycle and ethenyl (vinyl) hexene cycle, mainly) and straight chain (mainly heptane, octane and pentadecane $)^{[43]}$. 
- Non-condensable gas fraction is about $20 \%$ by weight and is composed mainly of hydrogen $\left(\mathrm{H}_{2}\right)$, hydrogen sulfide $\left(\mathrm{H}_{2} \mathrm{~S}\right)$, carbon oxides $\left(\mathrm{CO}_{\mathrm{x}}\right)$ and light hydrocarbons $\left(\mathrm{C}_{1}-\mathrm{C}_{6}\right)$, which can be used as fuel pyrolysis process or co-generation. It has a calorific value between $68-84 \mathrm{MJ} \mathrm{m}^{-3}[43]$.

- Solid residue is a mixture of steel and char or black carbon and accounting for $45 \%$ of initial weight.

Yields and composition depend on the temperature, pressure, residence time, particle size starting material, condensation temperature of the volatile fraction and the type of kilns used [36,37 and 39].

Despite the scientific research, there are few industrial plants in operation. At present, researchers focus their efforts on studying the kinetics of pyrolysis with ELTs under different conditions of temperature $\left(300-850{ }^{\circ} \mathrm{C}\right)$ and different proportions of oxygen $(5-21 \%)$ or nitrogen atmosphere, and to achieve cost-effective through different strategies for recovery.

There is one single industrial ELTs pyrolysis plant in Spain. It has the treatment capacity 16,500 t/year and it is a process and installing Spanish patent by the company PIROREC- B\&G S.L. in collaboration with the Polytechnic University of Valencia. There is another plant with a process called "Grau Thermic Tyres (GTT)", but this is a demonstration plant with the capacity of $500 \mathrm{t} /$ year developed by Enreco 2000 and the CSIC State Agency ${ }^{[43]}$.

The main advantage of pyrolysis technologies is to obtain products capable of recovery and a gas fraction that can be used as fuel in the process, as fuel in cement kilns or co-generation; tyre-derived oils have characteristics similar to a gas-oil trade being able to use as fuel in conventional furnaces and combustion engines, and the pyrolytic carbon black has great potential because it can enhance fuel substitution (when mixed with coal), absorbing light, the manufacture of polymeric materials, or as feedstock in the manufacture of charcoal and tyres. There is also an active Spanish technology. The most important drawback is the high cost of investment and process, and the price of the obtained products do not often justify a high-cost process due to competitive prices of the petroleum products.

\subsection{Gasification}

This is another thermal treatment technology which can use ELTs also. The thermal degradation of organic matter is carried out in the reactor under low-oxygen atmosphere $(1 / 3-1 / 5$ stoichiometric for complete combustion) and a temperature about $600{ }^{\circ} \mathrm{C}$ [44]. The result is a synthesis gas or syngas with an approximate yield of $63 \%$ by weight, and a solid phase representing about $37 \%$ about total weight. Yield gasification process varies depending on the technology, fuel and gasifying agent used ${ }^{[38}$ and 44]

The syngas has low calorific value $\left(5-6 \mathrm{MJ} \mathrm{Nm}^{-3}\right)$, and it is composed mainly of hydrogen $\left(\mathrm{H}_{2}\right)$ and carbon monoxide $(\mathrm{CO})$ which energy value can be used to produce electricity under specially adapted internal combustion engine, with relatively high yields, and free emissions of dioxins and furans. The gas is cleaned of particulates, tars and other components, and it is cooled to about $40^{\circ} \mathrm{C}$ before entering the motor generator. Today there are motors specially designed for operation with poor gas, the motor can to achieve yields about $37 \%$.

The solid fraction is composed of carbon black and steel. These are easily separated for material recycling.

There are two technologies ${ }^{[44]}$ :

- Entrained bed reactor, is subdivided depending on the relative sense of the flow fuel and gasification agent in "downdraft" where the streams are parallel, and "updraft" when travelling in the opposite direction.

- Fluidized bed reactor, a gasification agent has an inert and waste in suspension until the particles of ELTs is gasified, becoming flying ash and then, these are washed away from the syngas.

The biomass gasification such as agricultural and forest waste is a highly developed technology and is currently having a great success in the world, including Spain, but in the case of ELTs is yet in its development ${ }^{[45]}$. Spain has installed the first tire gasification plant in Europe in La Coruña (Garanesa) in 2003 by Guascor S.L. The company is the leader in this technology with FBLD series motors for recovery of the produced syngas. These motors have been specifically developed to operate with poor gas up to 4.5 $\mathrm{MJ} \mathrm{Nm}^{-3}$ in which fuel components are mainly carbon monoxide $(\mathrm{CO})$ and hydrogen $\left(\mathrm{H}_{2}\right)^{[45]}$.

This treatment obtains products capable of recovery and can be used as fuel for electrical or thermal energy, and in addition, Spain has an active national technology. The disadvantages, the difficulty of predicting the composition of the gas due to the variation of parameters and low-electrical yield of $25 \%$ compared with about $50 \%$ that can be achieved with biomass waste such as agricultural or forest ${ }^{[46-48]}$. 


\subsection{New plastic products}

The development of plastic products is growing. Shred tyre with binder thermoplastic or polyurethane can produce different materials and objects such as shoe soles, casings, insulating sheets, backs, motorcycle helmets, etc. ${ }^{[12]}$. New products from recycled rubber are a great opportunity for new applications emerging in the market for ELTs rubber. The biggest objection may come to doubt the quality and durability of the resulting materials, but it can be solved with the development of manuals and quality certificates.

\section{CONCLUSIONS}

- Europe leads policy on waste ELTs, and Spain includes guidelines and approach with its latest National Waste Plan 2008 - 2015 which marked the new goals to achieve in the management of ELTs.

- Producer Responsibility is the most widespread system for the management of ELTs in Europe. Spain musts continue to improve the emerging Producer Responsibility, and perhaps, coexistence of two IMS's is hindering the waste correct management, in the country.

- Life lengthening technologies of tyre, such as retreading, have a great development, since the Retreaded tyre production, in OECD countries, is a well-developed and mature industry.

- ELTs shredding and grinding technologies are widespread and a large market of companies that have covered this sector. But not all sizes produced have real application in the market today for which government support as well as industry awareness is required in order for used rubber derived products break into the market.

- Energy recovery of ELTs is a growing worldwide market, ranging from cement kilns to steel plants and any industrial boiler. In Spain, there is only recovery in cement kilns, but in the medium term are expected recoveries in industrial boilers and steel plants.

- Energy recovery technologies, such as pyrolysis and gasification, which have the added value of obtaining synthetic products, has created a new trend in tire recycling technology, using preshredded tyre.

- In general, the leaders in environmental technology sector expand its technology to this waste by seeing it as a new market with a tendency to grow.

- In this paper,the growth of that deal with tyre recycling have been checked. For 2000-2006, previous study by "CIMTAN (Círculo de Innovación en Materiales, Tecnología Aeroespacial y Nanotecnología)" in 2006, 142 articles were found using the command "tyre OR tire AND recycl*" in the application "Current Content Cunnect" of the database "ISI Web of Knowledge from Thomson", and in this report, we found 750 for the subsequent period 2006 - 2010, five times as many articles published in the period above.

- In order to achieve the expansion of emerging technologies is essential further research in the field process conditions, optimization, product characterization, and treatment is needed.

\section{Acknowledgements}

The authors wish to thank the ENRECO 2000 for funding this research. Also to State Agency CSIC for support. Special thanks to Dr. Juan Manso (ACUMENER Ltd.) for this technical assistance.

\section{REFERENCES}

[1] Spanish Law. Real Decreto 1619/2005, de 30 de diciembre, sobre la gestión de neumáticos fuera de uso. BOE, 3/01/2006 no. 2, p.352.

[2] Spanish Law. Orden MAM/304/2002, de 8 de febrero, por la que se publican las operaciones de valorización y eliminación de residuos y la lista europea de residuos (LER). BOE 19/2/2002, no. 43, p. 6.494 .

[3] J. Martínez, Guía para la gestión integral de residuos peligrosos. Fichas temáticas. Tomo II. Ed. Centro Coordinador del Convenio de Basilea para América Latina y el Caribe, Montevideo, Uruguay, 2005, pp. 21-26.

[4] M.Giannouli, P. de Haan, M.Keller and Z. Samaras, J.Cleaner Prod. 15 (2007) 1169. 1182

[5] Juniper Consultancy Services Ltd. Emerging solutions for managing scrap tyres. Tecnology solutions and market opportunities. Sheppards Mill (Ed.), Gloucestershire, England, 2004, pp. 22-23.

[6] Secretariat of Basel Convention, Technical guidelines on the identification and management of used tyres. United Nations Environment Programme (UNEP), 2000, pp. 1-47.

[7] E.Kwon and M.J.Castaldi. Environ. Sci. Technol. 43 (2009) 5996-6002.

[8] EU. Directiva 2008/98/CE del Parlamento Europeo y del Consejo, de 19 de noviembre 
THE RECYCLING OF END-OF-LIFE TYRES. TECHNOLOGICAL REVIEW RECICLADO DE NEUMÁTICOS FUERA DE USO. REVISIÓN TECNOLÓGICA

de 2008, sobre los residuos y por la que se derogan determinadas Directivas. Diario Oficial, 22/11/2008, n⿳⺈. L312, p. 3.

[9] Spanish Law. Real Decreto 1481/2001, de 27 de diciembre, por el que se regula la eliminación de residuos mediante depósito en vertedero. BOE, 29/01/2002, no. 25, p. 3.507 .

[10] UE. Directiva 2000/53/CE de 18 de septiembre de 2000 relativa a los vehículos al final de su vida útil. Diario Oficial, 21/10/2000, nº. L269, p. 34.

[11] Spanish Law. Real Decreto 653/2003, de 30 de mayo, sobre incineración de residuos. BOE, $14 / 06 / 2003, n^{\circ} .142$, p. 22.966.

[12] European Tyre \& Rubber Manufacturers Association (ETRMA). www. etrma. org

[13] Spanish Law. Resolución de 20 de enero de 2009, de la Secretaría de Estado de Cambio Climático, se aprueba el Plan Nacional Integrado de Residuos para el período 2008 2015. BOE, 26/02/2009, no. 49, p. 19.893.

[14] E. Cano, L. Cerezo and M. Urbina, Valorización material y energética de neumáticos fuera de uso. Informe de Vigilancia Tecnológica, Círculo de Innovación de Materiales, Tecnología Aeroespacial y Nanotecnología (CIMTAN) (Ed.),Madrid, Spain, 2006, pp. 1-100.

[15] Silke Krömer, Life Cycle Assessment of a car tyre, Continental AG (Ed.), Hannover, Germany, 2002, pp. 1-44.

[16] N.N. Eldin and A.B. Senouci, J. Mater. Civ. Eng. 5 (1993) 478-496.

[17] D. A. Baeta, J. A. Zattera, M. G. Oliveira and P. J. Oliveira, Braz. J. Chem. Eng. 26 (2009) 23-31.

[18] World Business Council for Sustainable Development (WBCSD), Managing-End-ofLife Tires, Full report, Washington, EE.UU., 2007, pp.1-18.

[19] Basel Convention, Revised technical guidelines on environmentally sound management of used tyres, UNEP (Ed.), Genova, Italy, 2010, pp. 1-56.

[20] S. Singh, W. Nimmo, B.M. Gibbs and P.T. Williams, Fuel 88 (2009) 2473-2480.

[21] L.H. Chou, C.K. Lu, J.R. Chang and M.T. Lee, Waste Manage. Res. 25 (2007) 68-76.

[22] J.A. Conesa, A. Gálvez, F. Mateos, I. MartínGullón and R. Font, J. Hazard. Mater. 158 (2008) 585-592.

[23] M.A. Trezza and A.N. Scian, Mater. Res. 2 (2009) 68-76.

[24] M. Zaharia, V. Sahajwalla, B.C. Kim, R. Khanna, N. Saha-Chaudhury, P. O`Kane, J. Dicker, C. Skidmore and D. Knights, Energy Fuels 23 (2009) 2467-2474.
[25] L. Zhou, Y. Wang, Q. Huang and J. Cai, Fuel Process. Technol. 87 (2006) 963-969.

[26] M. H. Joulazadeh, Int. J. ISSI 5 (2008) 36-40.

[27] Tetsuji Mino, Tyre Industry of Japan, JATMA (Ed.), Tokyo, Japan, 2009, pp. 1-32.

[28] J.I. Reisan, Air Emissions from Scrap Tire Combustion, United States Environmental Protection Agency (EPA) (Ed.), Research Paper EPA-600/R-97-115, California, United States, 1997, pp. 1-120.

[29] S. Singh, W. Nimmo, B. M. Gibbs and P. T. Williams, Fuel 88 (2009) 2473-2480.

[30] Centro de Estudios y Experimentación de Obras Públicas (CEDEX), Manual de empleo de caucho de NFU en mezclas bituminosas. Ministerio de Fomento and Ministerio de Medio Ambiente (Ed.), Madrid, Spain, 2007, pp.1-68.

[31] F. Hernandez-Olivares, B. Witoszek-Shultz, M. Alonso-Fernández and C. Benito-Moro, Int. J. Pavement Eng. 10 (2009) 277-288.

[32] I. Gawel and L. Slusarski, Polimery 43 (1998) 280-286.

[33] M. Alexandre-Franco and C.C. FernandezGonzalez, Energy Fuels 24 (2010) 3401-3409.

[34] M. Leary, Evaluation of Waste Tire Devulcanization Technologies, CalRecovery Inc. (Ed.) California, EE.UU., 2004, pp. 1-99. (Avaiable on line: http://www.calrecycle.ca.gov/Publications/Tires/ 62204008.pdf)

[35] F. A. López, F. J. Alguacil, A. López-Delgado and J. Manso, Situación actual del tratamiento de neumáticos fuera de uso y posibilidades de obtención de negro de humo de alta pureza, Digital CSIC, 2009, 1-25. (Avaiable on line: http://digital.csic.es/handle/10261/17979).

[36] S. Galvagno, S. Casu, T. Casablanca, A. Calabrese and G. Cornacchia, Waste Management 22 (2002) 917-923.

[37] S. Ucar, S. Karagoz, A. R. Ozkan and J. Yanik, Fuel 84 (2005) 1884-1892.

[38] F.A. López, T.A. Centeno, F.J. Alguacil, B. Lobato, A. López-Delgado and J. Grau Third International Symposium on Energy From Biomass and Waste Venice (Italy), Nov., 2010, IWWG (Ed.), Venice (Italy), pp. 21-39.

[39] M.F. Laresgoiti, B.M. Caballero, I. de Marco, A. Torres, M.A. Cabrero and M.J. Chomón, J. Anal. Appl. Pyrolysis, 79 (2007) 403-408.

[40] M. Olazar, M. Amutio, R. Aguado and J. Bilbao, Energy Fuels 23 (2009) 5423-5431.

[41] A. Akbar and M.A. Petrich, AIChE Journal 39 (1993) 1370-1376.

[42] M. Juma, Z. Korenova, J. Markos, L. Jelemensky and M. Bafrnec, Polym. Adv. Technol. 18 (2007) 144-148. 
[43] F.A. López, T.A. Centeno, F.J. Alguacil and B. Lobato, J. Hazard. Mater. 190 (2011) 285292.

[44] Besel S.A., Biomasa: Gasificación, Instituto para la Diversificación y Ahorro de la Energía (IDAE)(Ed.),Madrid, Spain, 2007, pp.1-36.

[45] T. Avelino, Eficiencia y ahorro energético en la industria agroalimentaria mediante gasificacion de biomasa, Guascor Bioenergía (Ed.), Álava, Spain, 2009, pp. 1-11.
[46] N.R. Mitta, S. Ferrel-Nadal, A.M. Lazovic, J.F. Perales, E. Velo and L. Puigjaner, Comput. -Aided Civ. Infrastruct. Eng. 21 (2006) 1771-1776.

[47] M. Treviño-Coca, Tecnología de gasificación integrada en ciclo combinado GICC. Aplicación real en España: ELCOGAS, Puertollano, ELCOGAS S.A., Club Español de la Energía, 2005, pp. 1-95.

[48] I. Silvestravi it and I. Karali nait 1, EREM 1 (2006) 52-60. 